\title{
Turtles of Kankai (Mai) river and their ethno-medicinal uses
}

\author{
Milan Kharel $^{1 *}$ and Damodar Thapa Chhetry ${ }^{2}$ \\ ${ }^{1}$ Department of Zoology, Lord Buddha College, Biratnagar, Nepal \\ ${ }^{2}$ Department of Zoology, P.G. Campus, Tribhuwan University, Biratnagar, Nepal \\ *E-mail: milankharel2000@yahoo.com
}

\begin{abstract}
This paper deals with 67 specimens belonging to eight different species out of which 4 species were hard-shelled turtles such as Indotestudo elongata, Melanochyles tricarinata, Melanochyles trijuga and Pangshura flaviventer, while rest of 4 species were soft-shelled turtles such as Lissemys punctata, Aspideretes hurum, Aspideretes gangeticus and Chitra indica. Among all, Lissemys punctata was recorded as widely distributed and most abundant species. Ethno-medicinal uses of turtle by Satar, an indigenous ethnic community of southern Jhapa for human and domestic animals have been documented. Most of the diseases are treated by the use of turtle shell of Lissemys punctata.
\end{abstract}

Key words: Turtle, Kankai river, Jhapa, anthropogenic impacts, Chelonian

\section{Introduction}

Jhapa district [Lat. $26^{\circ} 20^{\prime}$ to $26^{\circ} 50^{\prime} \mathrm{N}$ and the longitudes of $87^{\circ} 39^{\prime}$ to $87^{\circ} 12^{\prime} \mathrm{E}$; alt. 56 (Kechana Kalan) to $381 \mathrm{msl}$ (Sunmai and Nindatar); area $\left.1606 \mathrm{~km}^{2}\right]$ is located in subtropical region of eastern Nepal with a monsoon climate (Rai, 2003). Kankai (Mai) is the largest and holiest river of the district, originated from the george of mountain, flows southward to lowland of eastern Terai, enters into the Bihar state of India and joins the Ganges river, covering drainage area of about $1,150 \mathrm{~km}^{2}$ (Rai, 2004).

Records of Nepalese chelonian species date back to 150 years. Guenther described yellow elongated tortoise (Indotestudo elongata) for the first time from Nepal. An excellent summary of herpetological work done in Nepal up to 1960 is given by Swan and Leviton (1962). Shrestha (1997) made field work in different parts of eastern and western Nepal and gathered amphibians and reptiles from these areas. Chitra indica was reported from Kechana Jheel (Schleich, 2000) and Koshi Barrage (Schleich et al., 2002). There are 14 species of turtles recorded in Nepal (Schliech et al., 2002). Turtles and crocodiles need massy shallow wetlands habitats, many of which have been converted to agriculture land (Shrestha, 2002). Indotestudo elongate and Melanochelys tricarinata are rare in Nepal. Rai found Cyclenys oldhami at Tanting in the confinement of Dhobi Khola and Sakala Khola in the altitude of $280 \mathrm{~m}$ in August, 2001 (Schleich \& Kaestle, 2002).

The situation for the turtle fauna of Nepal is extremely bad. The frequent killing and selling by the local people has added further depletion in the number of turtle fauna. All the turtles of Nepal are under tremendous pressure from professional fishing man, tribal people, children and censorial collectors collecting the snails and turtles (Schleich et al., 2002). Rai (2006) reported L. punctata, Pangsura sp. and Melanochelys sp. from Chillagadh pond; 
Cyclemys oldhamii, and P. flaviventer from the Kankai river; and I. elongata from Khumaltar (Bahundagi), Peltimari (Chulachuli) and Khudunabari (Biring flood plain). Similarly, Melanochelys trijuga was recorded from Kankai River (Schleich et al., 2002; Rai, 2003). About $50 \%$ of total turtle species of Nepal (14 species) is recorded from Jhapa district but the habitat is vanishing drastically due to various anthropogenic impacts (Rai, 2006). Kankai (Mai) River was considered as the hot spot of turtle fauna after Kosi River but now it is not so (Rai, 2003). Shah (2004) reported that turtles are being overexploited as food and in the preparation of several traditional medicines as well as in making decorated artifact masks and curio items.

\section{Atudy area}

The study area covers the Kankai (Mai) River including its long and wide floodplains on either sides as well as forests, ponds, lakes and wetlands lying at its vicinities. The study area includes the survey route of about $30 \mathrm{~km}$ long starting from Domukha Dam at Maidhar $\left(26^{\circ} 25^{\prime} 49.4^{\prime \prime} \mathrm{N}\right.$ to $\left.87^{\circ} 40^{\prime} 31.0^{\prime \prime} \mathrm{E}\right)$ to Bhakurmari $\left(26^{\circ} 34^{\prime} 15.7^{\prime \prime} \mathrm{N}\right.$ to $\left.87^{\circ} 50^{\prime} 27^{\prime \prime} \mathrm{E}\right)$ Mahabhara VDC at south bordering Bihar state of India (Fig. 1).

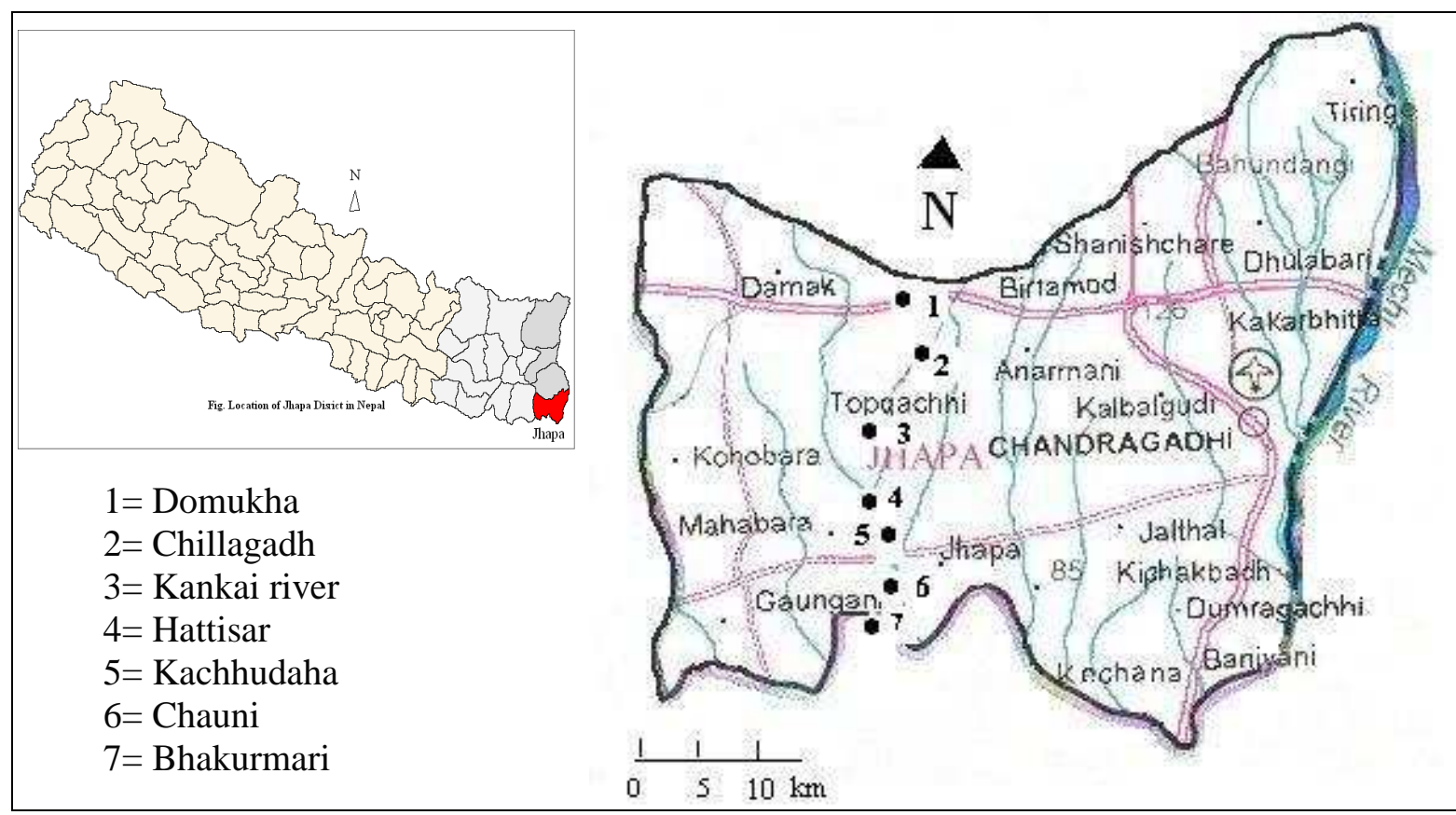

Figure 1. Survey route map of Jhapa showing different sampling stations.

\section{Materials and Methods}

\section{Data collection}

Information were collected through questionnaire and. Information were grouped and sub grouped and classified as necessary to meet the objectives of the study. Local people, officer, fisherman etc in addition to secondary data were collected from Gaide Meterological Center, DDC office, IUCN information, books, Journals and other reports. The study was based on general survey, carried out in the Satar communities settled in the vicinities of Kankai (Mai) River and its wide floodplains on either sides. Qualitative and quantitative data were obtained by employing questionnaire survey and structured interview technique. 
Households of Satar community in the study area were selected by random sample technique. Ethno-zoological information and details covering methods of preparation of traditional medicines from different parts or products of turtle and method of application of medicines were recorded from people of different ages (16-80 years).

\section{Sample collection technique}

In each visit, maximum effort was made to collect live specimens; but if not available, dead specimens were collected. They were collected with the help of nets, hooks and other measures like hand catching in the evening when the specimens come out from the aquatic habitat for food and retreat. Each time, attention was taken to collect eggs, juveniles, bones and shell elements. The captured living ones were collected in wet cloth bags and carried to the ARCO-TCC lab at Bhadrapur, Jhapa for the identification. The living specimens were released into the natural pond at the TCC-laboratory. The dead were preserved in $10 \%$ formalin with labeling and kept in the museum at TCC-Bhadrapur, Jhapa.

\section{Results and Discussion}

A total 67 specimens of turtles belonging to eight different species were recorded including their information and body elements like carapace, plastron, egg etc. Among these, 23 were recorded from Kankai River (at Domukha), 8 from Chillagadh pond, 6 from Hattisar floodplain area, 17 from Kachhudaha pond, 9 from Chauni wetland and 4 from TCC pond, Bhadrapur (Tab. 1, Fig. 2). Among them, four species were hard-shelled turtles such as Indotestudo elongata (5), Melanochyles tricarinata (3), Melanochyles trijuga (2) and Pangshura flaviventer (4), while rest of the four species were soft-shelled turtles such as Lissemys punctata (39), Aspideretes hurum (9), Aspideretes gangeticus (2) and Chitra indica (3) (Tab. 2).

Table 1. Number of turtles recorded in each sampling stations (Species wise).

\begin{tabular}{lllllll}
\hline Species & Domukha & Chillagadh & Hattisar & Kachhudaha & Chauni & TCC \\
\hline I. elongata & $1\left(^{\mathrm{inf}}\right)$ & $1\left(^{\mathrm{c}}\right)$ & - & - & - & $3\left(^{\mathrm{o}}\right)$ \\
M. tricraiata & - & - & $1\left(^{\mathrm{inf}}\right)$ & $2\left(^{\mathrm{inf}}\right)$ & - & - \\
M. trijuga & - & - & - & - & $2\left(1^{\mathrm{inf}}+1^{\mathrm{c}}\right)-$ \\
P. flaviventer & $1\left(\left(^{\mathrm{inf}}\right)\right.$ & - & $1\left(^{\mathrm{o}}\right)$ & $1\left(^{\mathrm{inf}}\right)$ & - & $1\left(^{\mathrm{c}}\right)$ \\
L. punctata & $16\left(3^{\mathrm{l}}++7^{\mathrm{c}}+6^{\mathrm{inf}}\right)$ & $6\left(3^{\mathrm{inf}}+2^{\mathrm{c}}+1^{\mathrm{o}}\right)$ & $3\left(2^{\mathrm{l}}+1^{\mathrm{c}}\right)$ & $9\left(4^{1}+1^{\mathrm{e}}+2^{\mathrm{inf}}+2^{\mathrm{o}}\right)$ & $4\left(2^{\mathrm{inf}}+2^{\mathrm{c}}\right)-$ \\
A. hurum & $3\left(2^{\mathrm{inf}}+1^{\mathrm{c}}\right)$ & $1\left(^{\mathrm{inf}}\right)$ & $1\left(^{\mathrm{c}}\right)$ & $2\left({ }^{\mathrm{o}}\right)$ & $2\left(1^{\mathrm{inf}}+1^{\mathrm{c}}\right)-$ \\
A. gangeticus & $1\left(^{\mathrm{inf}}\right)$ & - & - & $1\left(^{\mathrm{inf}}\right)$ & $1\left(^{\mathrm{inf}}\right)$ & - \\
C. indica & $1\left(^{\mathrm{inf}}\right)$ & - & - & $2\left(^{\mathrm{inf}}\right)$ & - & - \\
\hline Total & 23 & 8 & 6 & 17 & 9 & 4 \\
\hline
\end{tabular}

$\mathrm{l}=$ live, $\mathrm{o}=$ observed, $\mathrm{d}=$ dead, $\mathrm{c}=$ carapace, $\mathrm{Inf}=$ information, $-\mathrm{=}$ absent

According to Rai (2003), in Jhapa district both soft-shelled and hard-shelled turtles were found. In soft-shelled turtles of family Trionychidae, three genera viz. Lissemys punctata, Aspideretes sps, and Chitra indica were recorded whereas in hard-shelled turtles two families viz. Testudinidae and Bataguridae were recorded. Of which single genus Indotestudo elongata of Testudinidae family and Cyclemys oldhamii and Pangshura flaviventer of Bataguridae family were recorded. Locality records of some turtle species mentioned in previous research is found different in the present survey. Cyclemys oldhamii, 
Melanochelys tricraniata and Panshura flaviventer were collected from Kankai river but during present survey no such species were recorded. Schleich (2000) reported Chitra indica from Kechana Jheel and Melanochelys trijuga form Kankai river but these species could not be recorded from that area. Rai (2003) recorded altogether 37 number of turtles belonging to five species from Jhapa, out of which 18 turtles were Lissemys punctata and only two turtles were Melanochelys tricraniata.

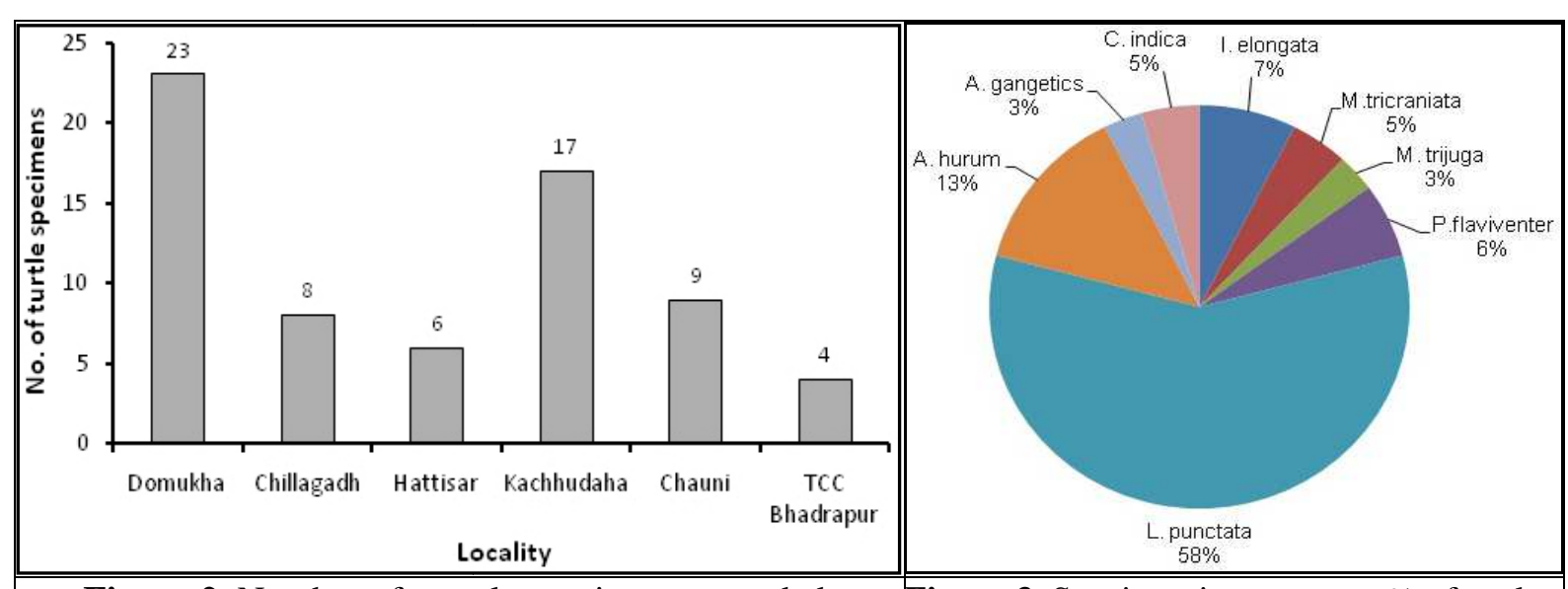

Figure 2. Number of sample specimens recorded.

Figure 3. Species-wise coverage $\%$ of turtles.

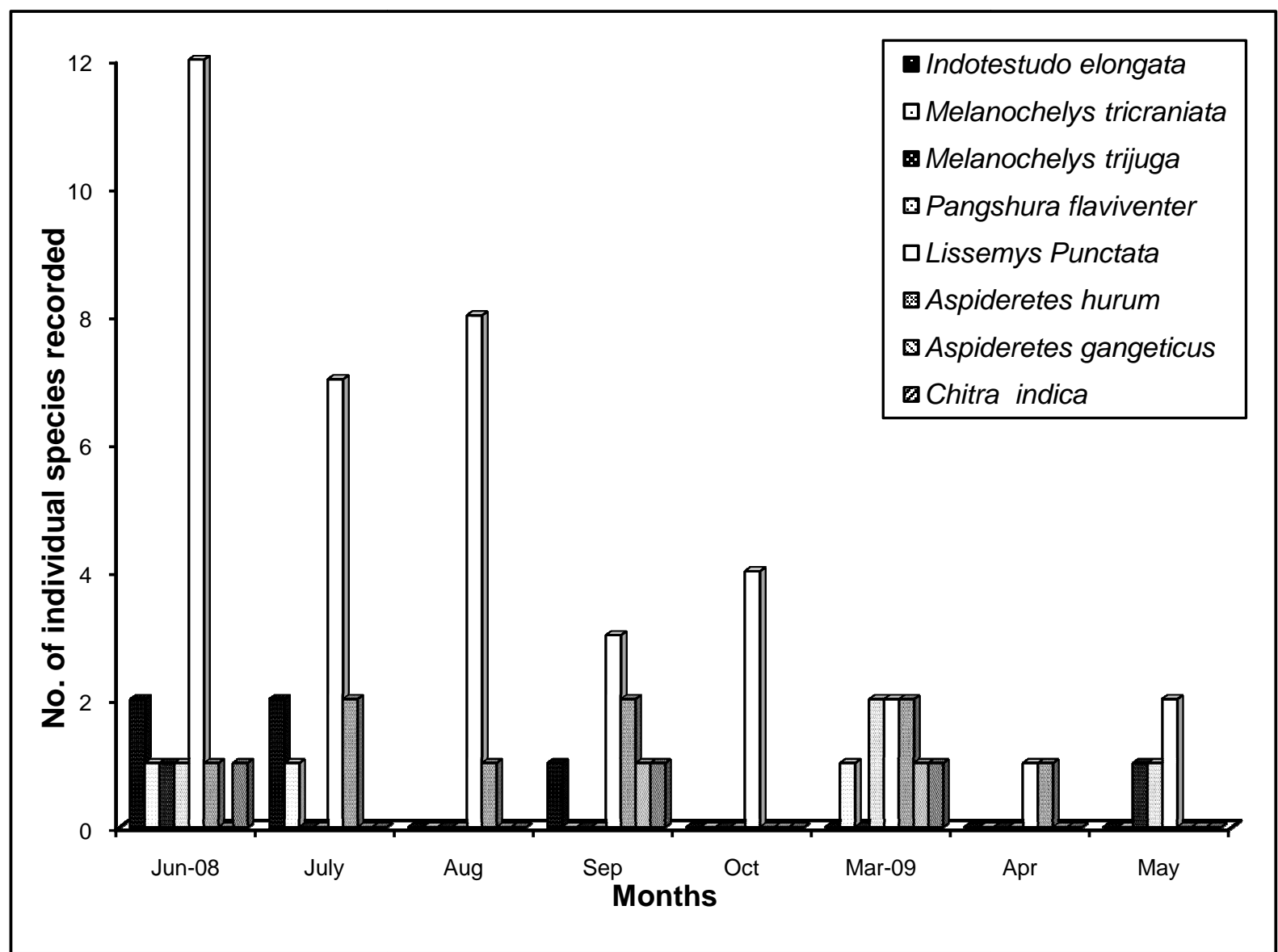

Figure 4. Monthly record of sample specimens 


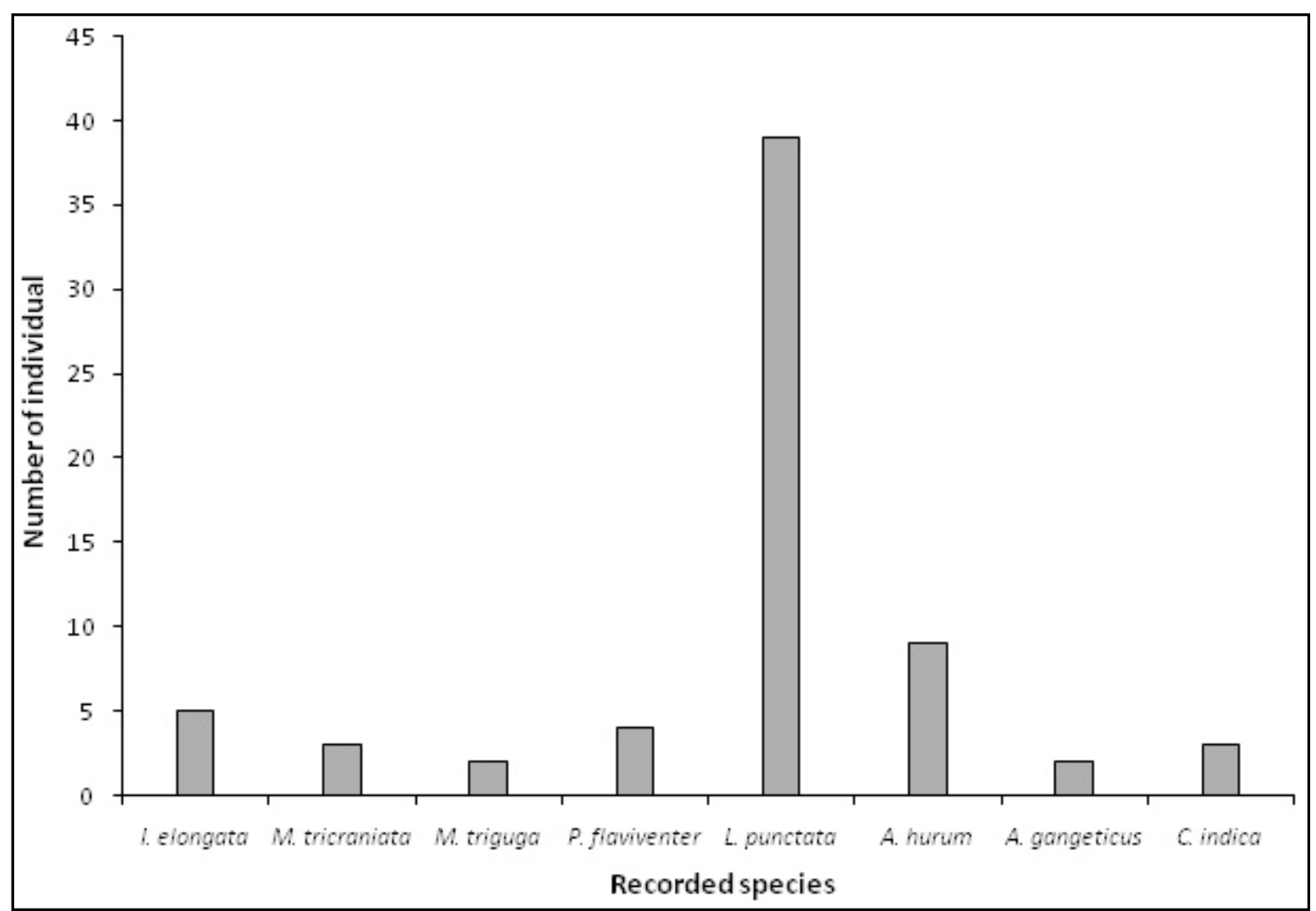

Figure 5. Species-wise number of turtle recorded.

Table 2. Distribution patterns of turtles at each sampling stations.

\begin{tabular}{lcccccc}
\hline \multirow{2}{*}{ Turtle specie } & \multicolumn{7}{c}{ Sampling stations } \\
\cline { 2 - 7 } & D & C & H & K & Ch & TCC \\
\hline Hard shelled: & & & & & & \\
Indotestudo elongata & + & + & - & - & - & + \\
Melanochelys tricraniata & - & - & + & + & - & - \\
M. trijuga & - & - & - & - & + & - \\
Pangshurea flaviventer & + & - & + & - & - & + \\
\hline Soft-shelled: & & & & & & \\
Lissemys punctata & + & + & + & + & + & - \\
Aspideretes hurum & + & + & + & + & + & - \\
A. gangeticus & + & - & - & + & + & - \\
Chitra indica & + & - & - & + & - & - \\
\hline D= Domukha, C= Chillagadh, H= Hattisar, K= Kachhudaha, Ch= \\
Chauni, TCC $=$ Turtle Conservation Centre, $+=$ present, $-=$ absent
\end{tabular}

Detailed survey and interviews were conducted to gather the information about details of the medicine preparation and uses to cure human and livestock diseases (Tab. 3). 
Table 3. Ethnomedical uses of turtle in southern Jhapa.

\begin{tabular}{|c|c|c|c|}
\hline $\begin{array}{l}\text { Body } \\
\text { parts }\end{array}$ & Utilities for & Methods of preparation & Methods of application \\
\hline \multirow{10}{*}{$\begin{array}{l}\text { Turtle } \\
\text { shell }\end{array}$} & Skin disease & $\begin{array}{l}\text { Burnt on the fire, then crushed to } \\
\text { fine powder and mixed with coconut } \\
\text { oil }\end{array}$ & $\begin{array}{l}\text { The preparation is applied on the } \\
\text { taffected regions }\end{array}$ \\
\hline & $\begin{array}{l}\text { Tonsillitis \& } \\
\text { Measles }\end{array}$ & $\begin{array}{l}\text { A paste is made by rubbing the shell } \\
\text { on a stone with water }\end{array}$ & Given orally to suffered children \\
\hline & Pneumonia & $\begin{array}{l}\text { Smoke produced by burning turtle's } \\
\text { shell }\end{array}$ & $\begin{array}{l}\text { Patient's naked body exposed to the } \\
\text { smoke }\end{array}$ \\
\hline & Labor pain & $\begin{array}{l}\text { A paste is made by rubbing the shell } \\
\text { on the stone with water }\end{array}$ & Given orally to minimize labor pain \\
\hline & Burns & $\begin{array}{l}\text { Ash produced by burning turtle's } \\
\text { shell }\end{array}$ & Applied to the affected area \\
\hline & Prosperity & Dried turtle's shell & $\begin{array}{l}\text { Kept in house and is believed to bring } \\
\text { prosperity }\end{array}$ \\
\hline & Milk production & TTalisman made from the turtle shell & $\begin{array}{l}\text { Tied around the neck of the milk } \\
\text { producing cattle }\end{array}$ \\
\hline & Eye irritation & $\begin{array}{l}\text { A thick dark black paste made by } \\
\text { burning }\end{array}$ & Put on the eyelids to treat eye irritation \\
\hline & Lucky charm & Talisman made from the turtle shell & Put below the pillow in house \\
\hline & Hydrocele & $\begin{array}{l}\text { A paste is made by rubbing the shell } \\
\text { on the stone with water }\end{array}$ & Applied to the affected region \\
\hline \multirow{2}{*}{$\begin{array}{l}\text { Turtle } \\
\text { bone }\end{array}$} & Evil spirit & Talisman made from turtle's bone & $\begin{array}{l}\text { Tied around their neck to get rid of evil } \\
\text { spirit }\end{array}$ \\
\hline & Dysentery & Talisman made from turtle's bone & Put under the pillow of the patient \\
\hline $\begin{array}{l}\text { Turtle } \\
\text { meat }\end{array}$ & Asthma & $\begin{array}{l}\text { Cooked flesh after boiling with ash- } \\
\text { water. }\end{array}$ & Eaten to avoid asthma \\
\hline $\begin{array}{l}\text { Turtle } \\
\text { urine }\end{array}$ & Kidney disease & Collected in an earthen pot & $\begin{array}{l}\text { Given orally to the patient to cure } \\
\text { disease }\end{array}$ \\
\hline $\begin{array}{l}\text { Turtle } \\
\text { egg }\end{array}$ & $\begin{array}{l}\text { Stomach } \\
\text { cramps }\end{array}$ & $\begin{array}{l}\text { Paste made up of dried out eggs of } \\
\text { turtles }\end{array}$ & Either eaten or applied on the stomach \\
\hline $\begin{array}{l}\text { Turtle } \\
\text { heart }\end{array}$ & Witchcraft & Dried turtle heart & To perform witchcraft \\
\hline $\begin{array}{l}\text { Turtle } \\
\text { bile }\end{array}$ & Tuberculosis & Collected bile & $\begin{array}{l}\text { Given orally to the patient for } 10-15 \\
\text { days to treat newly developed } \\
\text { tuberculosis }\end{array}$ \\
\hline $\begin{array}{l}\text { Turtle } \\
\text { blood }\end{array}$ & $\begin{array}{l}\text { Blood } \\
\text { production }\end{array}$ & Fresh blood & $\begin{array}{l}\text { Drink with alcohol to enhance blood } \\
\text { production in the body }\end{array}$ \\
\hline $\begin{array}{l}\text { Gall } \\
\text { bladder }\end{array}$ & Migraine pain & $\begin{array}{l}\text { Gall Bladder of Indotestudo } \\
\text { elongata }\end{array}$ & Given orally to reduce migraine pain \\
\hline $\begin{array}{l}\text { Turtle } \\
\text { penis }\end{array}$ & Hysteria & $\begin{array}{l}\text { Turtle's penis rubbed on the stone } \\
\text { with water }\end{array}$ & Given orally to treat hysteria \\
\hline \multicolumn{2}{|c|}{ Turtle fat Weak bone } & Oil extracted by heating turtle fat & $\begin{array}{l}\text { Massaged on the limbs of a baby who } \\
\text { is unable to walk properly }\end{array}$ \\
\hline
\end{tabular}

There is no scientific reason to use turtle shells for medical or pharmaceutical treatments. The use of turtle bone is nothing more than a useless case of superstition (Schleich, 2000). The major factors responsible for the utilization of turtle in the preparation of traditional 
medicines seem to be due to non-availability of modern medicines for the traditional substitute, superstitions and perhaps low cost treatment (Shah, 2004). These preparations never have been scientifically tested for their efficacy in Nepal. Some of the traditional medicines prepared from the turtle's body parts, eggs may have some healing properties, and partly effective against diseases, however, others seem working only on faith. These remedies are also useful to relieve fear and shock in the patient. Thus, overexploitation of turtles and their eggs for local consumption for food and in the preparation of traditional medicines definitely threat the survival of turtle species from the wetlands of south-east Nepal. Thus immediate steps are necessary to control their exploitation.

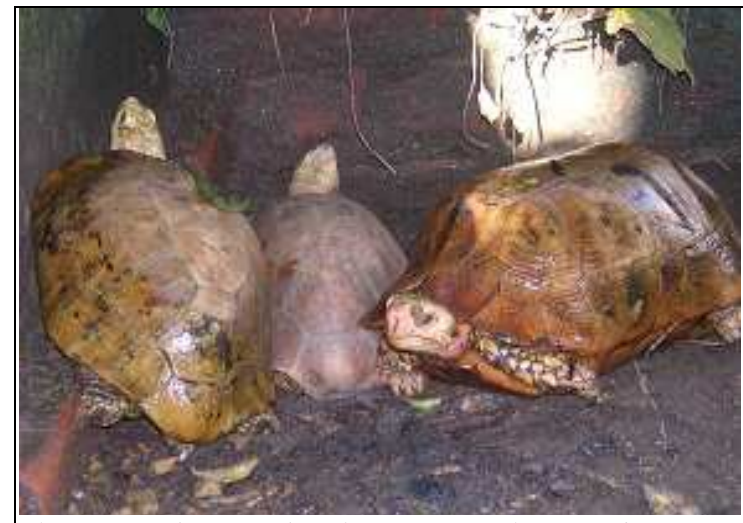

Plate 1.Indotestudo elongata under ex-situ conservation

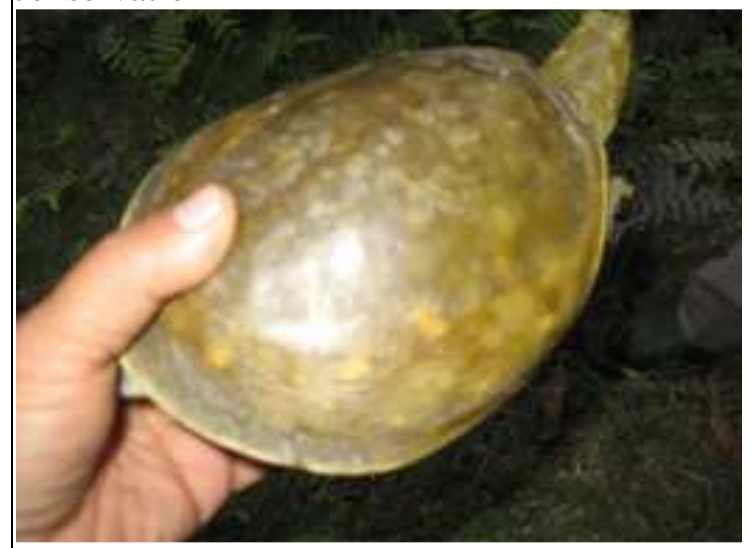

Plate 3. Lissemys punctata (Dorsal view)

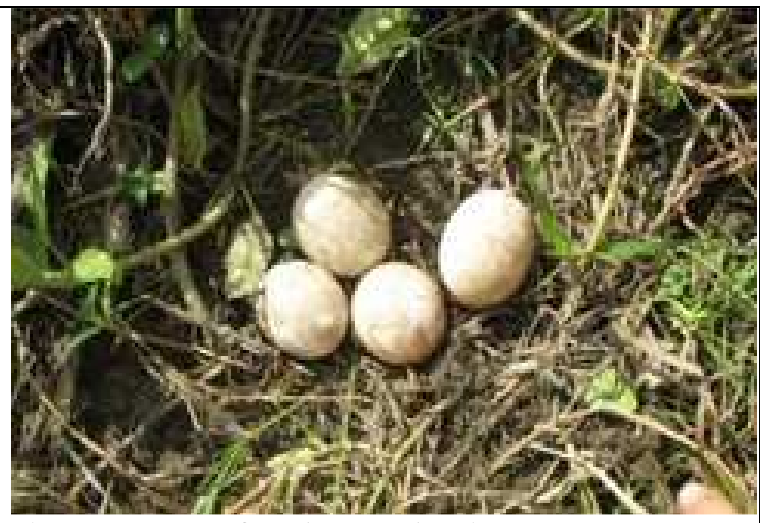

Plate 2. Eggs of Indotestudo elongata at ARCOTCC

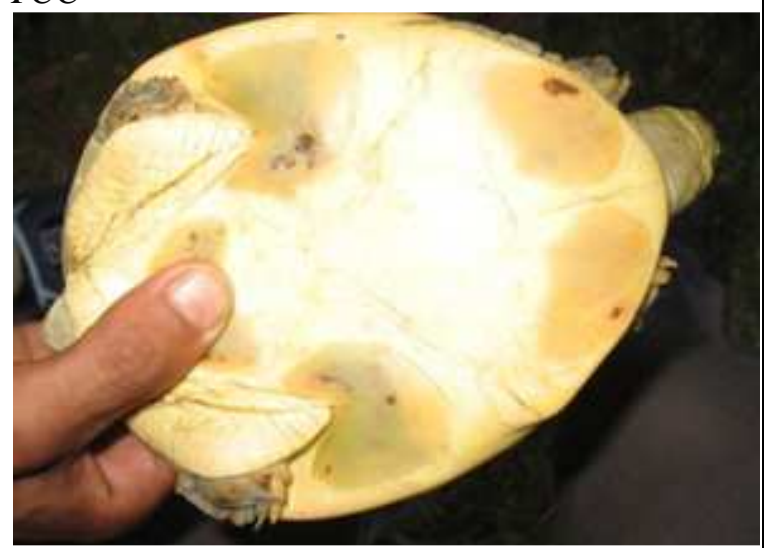

Plate 4. Lissemys punctata (Ventral view)

Plates 1-4. Some collected specimens of Turtle.

The conclusion of the present work is that the distribution pattern of turtles in Kankai (Mai) river and its vicinities is not regular. Compared to previous record, out of seven recorded species, this time live specimens belonged to only three species. Rest of the species might have disappeared due to human impacts, especially due to encroachment of wetlands and other potential habitats. However, frequencies of Lissemys punctata were recorded maximum during specimen collection.

\section{Acknowledgements}

Thanks are due to Head, Department of Zoology, Post-Graduate Campus, Biratnagar for facilities. Thanks are also due to Prof. Dr. K.R. Rai 'Khambu', HOD Zoology, Mechi 
Multiple Campus, Bhadrapur for his continuous guidance, inspiration, personal assistance during field trip and supply of useful literature. The first author is grateful to founder of ARCO Nepal, Prof. Dr. H. Hermann Schleich, University of Munich (Germany) and NAST for providing financial assistance to conduct this study.

\section{References}

Rai, K.R. 2003. Environmental Impact Systematics and Distribution of Herpetofauna from East Nepal. Ph.D. Thesis, Central Department of Zoology, T.U., Kritipur, Kathmandu.

Schleich, H. \& W. Kaestle (Eds.) 2002. Amphibian and Reptiles of Nepal. Biology, Systematics, Field Guide, A.R.G. Gantner Verlag K.G., Germany. pp. 501-570.

Schleich, H.H., K. Ernst \& T.M. Maskey 2002. Urgent Call for Turtle Conservation in Nepal. In: Nepal Myths and Realities (Ed. R.B. Thapa \& J. Baaden). pp. 307-326.

Schleich, H.H. 2000. The Turtles of Nepal. A Children Coloring Book, Pub. ARCO Nepal Reg. Soc. Fuhlrott-Museum. 34p.

Shah, K.B. 2004. Ethnozoology of the Turtles in Nepal. J. Nat. Hist. Mus. (13): 19-30.

Shrestha, T.K. 2002. Herpetology of Nepal. A Study of Amphibians and Reptiles of TransHimalayan Region of Nepal, India, Pakistan and Bhutan. pp.1-270.

Shrestha, T.K. 1997. Status, biology, conservation and management of tortoises and turtles in the Himalayan foothills of Nepal. Kathmandu, Nepal. 280p.

Swan, L.W. \& A.E. Levinton. 1962. The Herpetology of Nepal. A history checklist and zoogeographical animals of the herpetofauna. Academic Press, London and New York, pp. 311-339.

Schleich, H. H., Kaestle W. \& Rai, K.R. Eds. 2002. Amphibian and Reptiles of Nepal. Biology, Systematics, Field Guide, A.R.G. Gantner Verlag K.G, Germany, pp.501-570.

Rai, K.R. 2004. Ecological distribution of Cyclemys oldhamii (Grey, 1863) from Nepal. Our Nature 2: 7-13.

Rai, K.R. 2006. Anthropogenic impacts on Herpetofauna: with reference to Science Education in Nepal. J. Nat. Hist. Mus. 22: 14-21. 